\title{
原研における事故対応ロボットの開発（その2） 耐環境型ロボットの開発
}

Development of Rescue Robot at JAERI - Part 2 Development of Radiation-Proof Robot-

柴 沼清* *日本原子力研究所東海研究所核融合工学部炉構造研究室

Kiyoshi Shibanuma* *Japan Atomic Energy Research Institute

\section{1. はじめに}

平成 11 年 9 月末に発生した JCO の臨界事故では, 放射 線レベルが高く，事故現場への人のアクセスが困難であっ た.このため, 事故現場の状況についての情報が不十分で, 事故の収拾を大幅に遅らせた。この JCO 事故のように，原 子力施設で事故が発生し，放射線により人がアクセスでき ない場合，事故をできるだけ早く収拾するために，事故現 場に侵入し，情報収集や事故拡大防止・停止処置作業を行 うロボットの開発が必要となる $[1]$.

日本原子力研究所では，これまで原子力施設用ロボット および核融合炉用保守ロボットの開発を通して養ってきた 知見や経験などを生かして [2], 事故時情報遠隔収集ロボッ ト」(RESQ: Remote Surveillance Squad) の開発 [3] と 並行して，より放射線レベルの高い環境下で作業が可能な 「耐環境型ロボット」(RaBOT: Radiation-proof Robot) の開発を進めている.

\section{2. 開発の経 緯}

原子力施設の事故対応ロボットを開発するに当たり，ま ずロボットに必要とされる機能などを検討するため, 要求 される作業目的とその作業対象をマトリックス状に整理し た（表 1)。これより，ドアや階段などを容易に走行できる ロボットのコンパクトさを要求する一方で, 多種多様な情 報収集および事故時の作業が要求される。このため，すべ ての要求を 1 台のロボットで満足させることは困難であり, 複数のロボットが必要となる。 そこで, 今回開発するロボッ 卜は，事故拡大防止・停止処置の作業を行うことを主目的 に, 将来の改造と高度化を想定し, 最終的には表 1 の網掛 け部分の機能を満足するロボットとした。

さらに，核融合炉用保守ロボットの開発を通して蓄積さ れた耐放射線技術を基に [4], RESQ では作業が制限され

\footnotetext{
原稿受付 2001 年 5 月 2 日

キーワード: Rescue Robot, Radiation-proof, Remotely Changeable Modules, Crawler, Dual Manipulators, Remote Control

* $\bar{T} 319-1195$ 茨城県那珂郡東海村白方白根 2-4

${ }^{*}$ Naka-gun, Ibaraki
}

る，より高い放射線環境下においても，人に代わって情報 収集や作業を行うことができる耐放射線性に優れたロボッ トを開発対象とした。

\section{3. ロボットの概要}

今回開発した RaBOT の主要諸元および外形図を表 2, 図 1 に示す。本ロボットは，映像，音声および距離情報を 収集するための機器を搭載した頭部, 複雑作業が可能な双 腕型バイラテラル・マスタースレーブ・マニピュレータ, 階 段, 段差, 堰等の走行上障害となる構造物に対しても安定 な走行が可能な独立 4 クローラと重心移動機構から構成さ れる [5]. なお，走行時におけるロボットの重心移動は，口 ボットの上半身が走行台車上で円弧状に前後することによ り行われる。ロボットの大きさは，一般的なドアと階段を 容易に通過できるという条件から決定され，70 [cm] 幅とし た. 走行性能は, 平地での速度 $2[\mathrm{~km} / \mathrm{h}]$, 階段斜度 30 度 とした。各マニピュレータの可搬容量は $15[\mathrm{~kg}]$ とし, ドア の開閉やバルブの開閉には，マニピュレータの先端部に取 り付けた専用ッールを使用する。これらのッールの交換も ロボット自身が行う。ロボットには，ロボット頭部の 2 台 を含めて, 左右 (2台), 後方 (1 台), マニピュレータ手先 （2台）に合計 7 台の監視用カメラを設置した。また，頭部 に設置された距離センサーにより，対象物までの距離計測 や対象物の形状計測を行うことができる.

ロボットの操作には, 有線または無線を使用し, 操作盤 を備えた専用のコンテナ内から 1 人または 2 人のオペレー 夕がロボットから送られてくる映像情報を画面で見ながら 操作を行う。オペレータが 1 人の場合，マニピュレー夕は マスターアームにより，クローラはペダルまたはジョイス ティックにより操作される． 2 人の場合，マニピュレータと クローラの操作を分担して行う. ロボットが収集した情報 はすべてコンテナ内の計算機で集中管理される.なお, 無 線運転の場合のバッテリの仕様として, 2 時間以上の連続 作業を想定し, リチウム・イオン二次電池を採用した。

本ロボットの耐放射線性について，耐放射線性に関する データが不十分であったバッテリや電源などについて，耐 放射線性試験を実施し，デー夕を収集した，図 2 に耐放射 
表 1 作業目的と作業対象

\begin{tabular}{|c|c|c|c|c|c|c|c|}
\hline \multirow{2}{*}{ 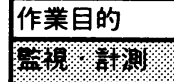 } & \multicolumn{7}{|c|}{ 作業対象 } \\
\hline & 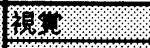 & 放射線 & 寄囲気 & 気象 & (耳) & The & 重量 \\
\hline \multirow{4}{*}{ 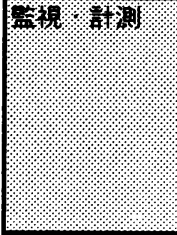 } & 等明的 & $\alpha$ 線 & ガス & 温度 & 鬲 & & \\
\hline & 超音波撮影 & & FP & 風向 & |超音波 & & \\
\hline & 赤外線撮影 & $\begin{array}{l}r \text { 線 } \\
\text { 中性子線 }\end{array}$ & 煙泿度 & \begin{tabular}{|l} 
風速 \\
湿度
\end{tabular} & & & \\
\hline & & & & 震度 & & & \\
\hline \multirow[t]{6}{*}{ Th? } & ET: & 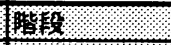 & 野外 & 高所位重 & 配管内部 & 水中 & \\
\hline & Wrif: & 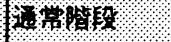 & Рスファルト & 空中 & 冷却配管 & 純水 & \\
\hline & 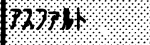 & & 籓越え & 天井 & 排水管 & 海水 & \\
\hline & 14. & らせん階段 & & 壁 & 空気配管 & 特殊溶刘 & \\
\hline & 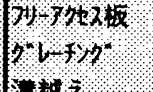 & はしご & $\begin{array}{l}\text { ダート } \\
\text { 砂 }\end{array}$ & & & & \\
\hline & Let) & & 雪面 & & & & \\
\hline \multirow[t]{5}{*}{ 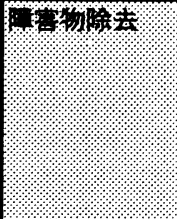 } & 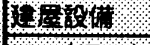 & O & 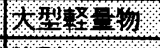 & 小型重量物 & 大型重量物 & 泥 - 砂状物 & 液体 \\
\hline & "? (押) & (箯型 & 籍型 & & & 化学反応物 & 水 \\
\hline & 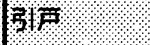 & wa & I球型 & 球型 & 球型 & & \\
\hline & 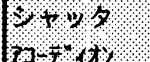 & 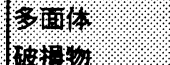 & S & 多面体 & $\begin{array}{l}\text { 多面体 } \\
\text { 破相物 }\end{array}$ & 砂 & \\
\hline & & 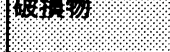 & & & & & \\
\hline \multirow{5}{*}{ 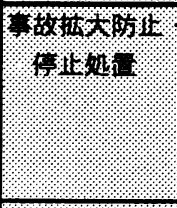 } & 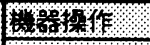 & 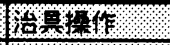 & 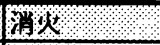 & 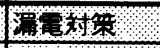 & 化学反応 & 中継作業 & \\
\hline & W & tery) & bex & 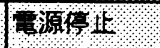 & 中和郕 & 木-र & \\
\hline & 6 & 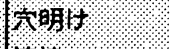 & 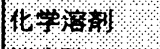 & $7 \rightarrow+1$ t & 反応停止剂 & ケ-ブル & \\
\hline & $14: 140$ & & 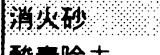 & & & & \\
\hline & 14 \% & & 酸素除去 & & & & \\
\hline \multirow[t]{2}{*}{ ( (1) } & 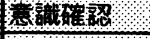 & Mトドリグ & 搬送 & & & & \\
\hline & 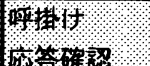 & $\begin{array}{l}\text { 抱きかかえ } \\
\text { 引きトげ }\end{array}$ & 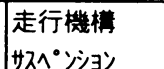 & & & & \\
\hline \multirow[t]{3}{*}{ 污染拡散防止 } & 遮蔽壁 & フィルタ & ハンドリグ & 搬送 & & & \\
\hline & כシクリ-ト & 土衰 & 重量物 & 重量物 & & & \\
\hline & \begin{tabular}{|l} 
鉛 \\
硼酸
\end{tabular} & $\begin{array}{l}\text { 粘土 } \\
\text { 砂 }\end{array}$ & 危険物 & 危険物 & & & \\
\hline \multirow[t]{7}{*}{ 除染 } & 霃洩物除去 & 機械式除染 & & 化学除染 & 污染水 & 非接触処理 & \\
\hline & 吸引 & Mイドロジェ帅 & & 化学除染剂 & 水中脱塩 & t゙ Z- Hシ-ト & \\
\hline & すくいとり & 吸引 & & フルホン洗浄 & 蒸留 & & \\
\hline & 掻き出し & こすり取り & & & & & \\
\hline & & ㅈリッパブルコ一ラ & & & & & \\
\hline & & $\mid \begin{array}{l}\text { 床研磨 } \\
\text { 不-ムジ エ卟 }\end{array}$ & & & & & \\
\hline & & 超音波 & & & & & \\
\hline \multirow{4}{*}{$\begin{array}{l}\text { 現場片づけ } \\
\text { 作業員支援 }\end{array}$} & 遮蔽 & ハハドリグ & 搬送 & 安全対策 & 作業支援 & & \\
\hline & $r$ 線 & 重量物 & 重量物 & 放射線センサ & トラシシーバ & & \\
\hline & 中性子線 & 危険物 & 危険物 & 被䏆管理 & 映像 & & \\
\hline & & & & & 写真 & - & \\
\hline \multirow[t]{5}{*}{ 検查支援 } & 遮蔽 & ハハドリング & 搬送 & 安全対策 & 作業支援 & 也搭載 & \\
\hline & $\gamma$ 線 & 重量物 & 重量物 & 放射線セ隌 & トラシシール゙ & FPザプリング & \\
\hline & 中性子線 & 危険物 & 危険物 & 被曝管理 & 映像 & 放射能計測 & \\
\hline & & & & & \begin{tabular}{|l} 
写真 \\
計算機
\end{tabular} & |サ-モグラフ1 & \\
\hline & & & & & $\angle A N$ & & \\
\hline
\end{tabular}


表 2 RaBOT の主要緒元

\begin{tabular}{|c|c|}
\hline 項目 & 主要諸元 \\
\hline 情報収集·作業機能 & $\begin{array}{l}\cdot \text { ·画像 } \\
\cdot \text { 音 } \\
\cdot \text { 距離計測 } \\
\text { ·試料採取 } \\
\cdot \text { 㕕開閉 } \\
\cdot \text { 釦操作 } \\
\cdot \text { 扉開閉 } \\
\cdot \text { 扉開錠 }\end{array}$ \\
\hline 耐放射線性（集積線量） & 約 $10^{5}$ Gy (ただし、電子部品約 $10^{2}$ Gy、ユニット交換により延命) \\
\hline マニピュレータ & $\begin{array}{l}\text { 双腕 } 7 \text { 自由度、可搬容量 : } 15 \mathrm{~kg} \text { (片腕) 、 } \\
\text { パイラテラル・マスター・スレーブ方式を採用 }\end{array}$ \\
\hline エンド·エフェク夕 & マニピュレータ先端部で着脱が可能（ワンタッチ・コネクタ使用） \\
\hline 走行機構 & $\begin{array}{c}\text { 左右独立 } 4 \text { クローラ(前·後進、旋回、停止)、最小回転直径: } 1116 \mathrm{~mm} \text { 、 } \\
\text { 段差 : } 220 \mathrm{~mm} \text { 以下、階段・障害物走行時の安定化のためトルク制 } \\
\text { 御·重心位置制御を採用 }\end{array}$ \\
\hline 走行速度 & 約 $2.0 \mathrm{~km} / \mathrm{h}$ \\
\hline 階段昇降 & 最大斜度 30 度 \\
\hline 動力源 & $\begin{array}{c}\text { 商用電源またはバッテリ（2 時間の連続運転が可能） } \\
\text { ハイッテリはリチウム・イオン二二次電池 }\end{array}$ \\
\hline 監視用カメラ & $\begin{array}{l}\text { 頭部 : 左右ステレオカメラ、ズーム・パン・チルト機能付き } \\
\text { マニビュレータ : 左右手先カメラ、固定焦点 } \\
\text { 走行台車 : 後部·側方 (左右) カメラ、固定焦点、合計 } 7 \text { 台 }\end{array}$ \\
\hline 距離センサー & 測定範囲：1 5 m、分解能：1 5 mm \\
\hline 操作方式 & 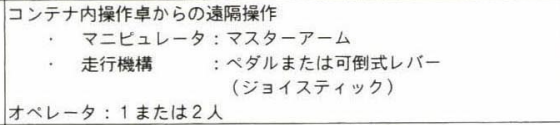 \\
\hline 外径寸法 & $\begin{array}{c}\text { 幅 } 700 \mathrm{~mm} 、 \text { 長さ } 1200 \mathrm{~mm} \text { 、高さ } 1300 \mathrm{~mm} \\
\text { (なお、階段の踊り場走行時には、4 } 4 \text { クーラを倒立し、 } \\
\text { 最小断面 : 幅 } 700 \mathrm{~mm} \text { 、長さ } 870 \mathrm{~mm} ） \\
\end{array}$ \\
\hline 重量 & 約 $450 \mathrm{~kg}$ \\
\hline
\end{tabular}

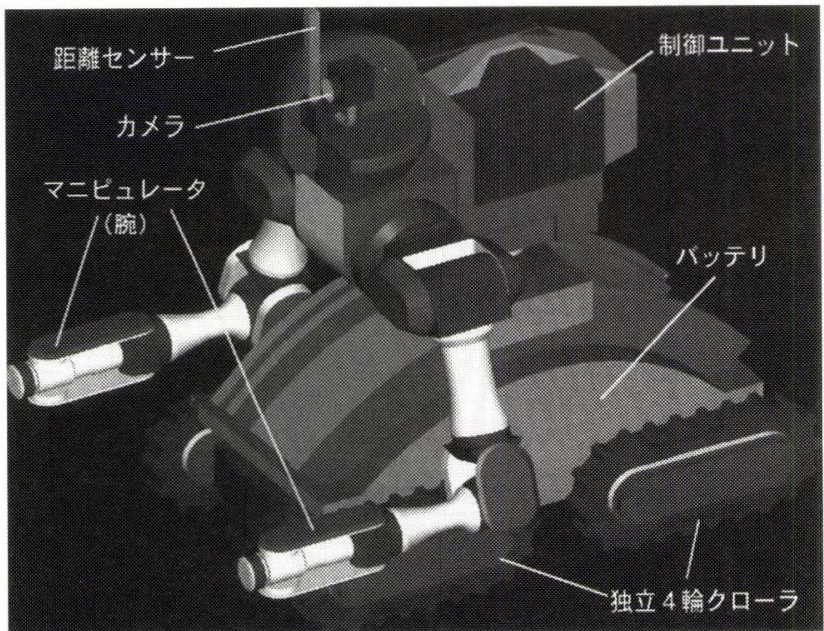

図 1 耐環境型ロボットの外形図

線性試験の一例として，バッテリのガンマ線照射下におけ る放電特性を示す。非照射の場合と比較して差異がないこ とから，バッテリはロボットの仕様である $10^{5}[\mathrm{~Gy}]$ までの 耐放射線性を満足することが確認できた。これらのデー夕 を基に，耐放射線性に優れた部品をできるだけロボットに 搭載した。耐放射線性が低いカメラなどの電子部品はユニッ ト化し，他のロボットを使って現場で容易に交換できる設 計とした。各ユニットの構造と設置場所の概略を図 3 に示 す.なお，各ユニットの重量は，マニピュレータの可搬容量 $15[\mathrm{~kg}]$ を考慮し，10 $[\mathrm{kg}]$ 以下とした。本ロボットは，耐放 射線性の低い部品が寿命に達した場合，現場で他のロボッ

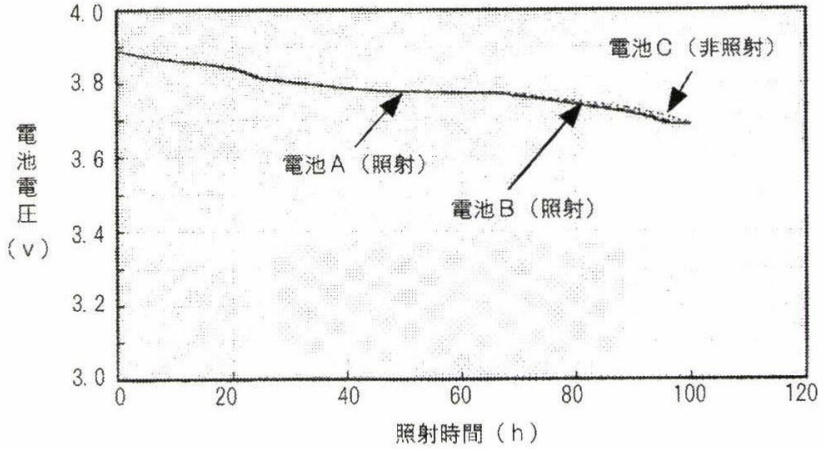

図 2 バッテリのガンマ線照射下における放電特性試験結果

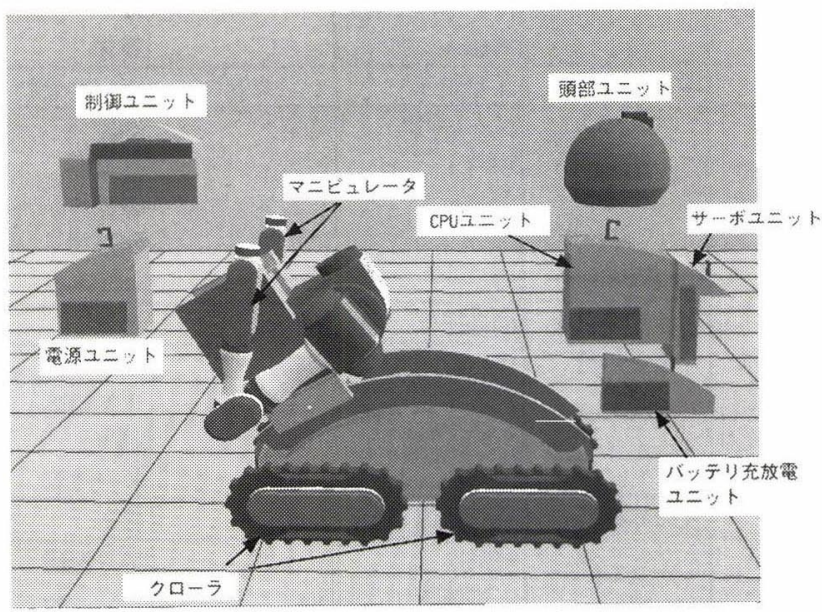

図 3 ユニットの構造とそのレイアウト

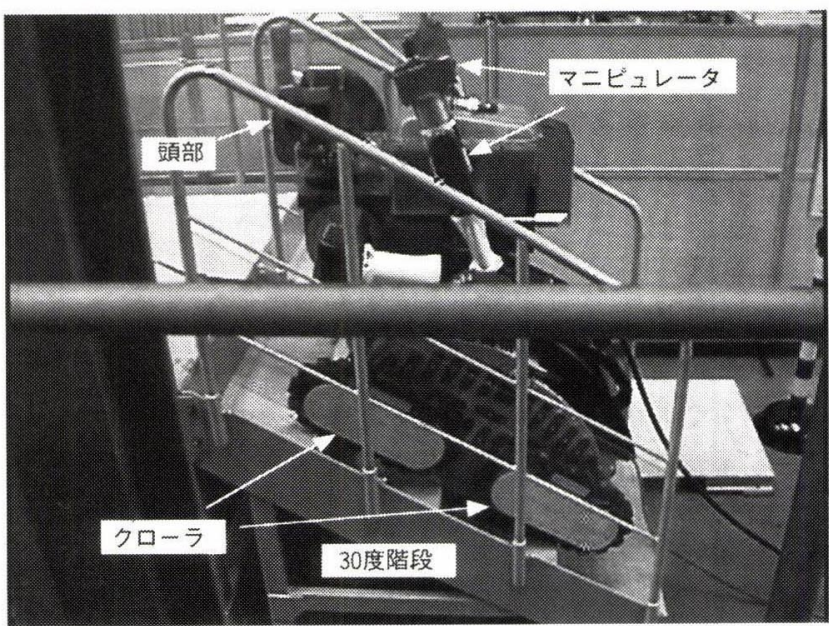

図 4 階段走行試験の実施例

卜使って部品を交換し, 作業を続けることが可能であり, 作 業の効率化が期待できる.

RaBOT は, 平成 13 年 7 月に原研に納入され, 現在各 種試験を実施中である。一例として，30 度階段の走行試験 の様子を図 4 に示す. 


\section{参 考 文 献}

（1］妻木俊道：“危険作業ロボット”, 日本ロボット学会誌, vol.18, no.7, pp.946-950, 2000

[2]多田栄介, 柴沼清：“国際熱核融合実験炉（ITER）の遠隔保守”, プ ラズマ・核融合学会誌, vol.73, no.1, pp.21-28, 1997.

[3] 小林, 宮島, 柳原：“原研における事故対応ロボットの開発（その1) 情報収集ロボットの開発”, 日本ロボット学会誌, vol.19, no.6, 2001.

[4] 岡, 小原, 角舘, 富永, 赤田, 森田: “耐放射線性機器の開発”, プラ ズマ・核融合学会誌, vol.73, no.1, pp.69-82, 1997.

[5] S. Hirose, T. Sensu and S. Aoki: "The TAQT Carrier: A Prac- tical Terain-Adaptive Quadru-Track Carrier Robot," Proc. IEEE/RSJ Int. Conf. On Intelligent Robots and Systems, pp. 2068-2073, 1992.

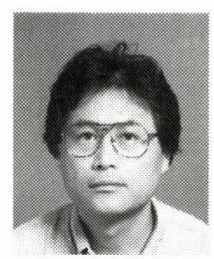

\section{柴沼 清 (Kiyoshi Shibanuma)}

1954 年生. 1980 年早稲田大学理工学研究科 修上課程修了. 同年日本原子力研究所入所. 核 融合実験炉の保守用遠隔ロボットの研究開発 に従事。工学博士. 日本原子力学会，プラズ マ・核融合学会の会員. 